ZOOLOGIA 31 (6): 561-576, December, 2014

http://dx.doi.org/10.1590/S1984-46702014000600005

\title{
A review of Scatellini (Diptera: Ephydridae) from Brazil
}

\author{
Wayne N. Mathis ${ }^{1}$, Luciane Marinoni² \& Daniel N.R. Costa ${ }^{2}$
}

\author{
${ }^{1}$ Department of Entomology, NHB 169, PO Box 37012, Smithsonian Institution, Washington, D.C. 20013-7012, United \\ States. E-mail: mathisw@si.edu \\ ${ }^{2}$ Departamento de Zoologia, Universidade Federal do Paraná. Caixa Postal 19020, 81531-980 Curitiba, PR, Brazil. \\ E-mail: Imarinoni@ufpr.br; negosekidan@ufpr.br
}

\begin{abstract}
Scatellini was proposed by Wirth \& Stone, 1956 and currently includes 242 described species in nine genera. The tribe has representatives in all biogeographic regions and about 70 species occur in the Neotropical Region. Prior to this study, only two species were recorded from Brazil: Scatella obscura and Limnellia itatiaia. In this paper, species of Scatellini from Brazil are reviewed with an emphasis on the fauna from southern Brazil, where six new species have been discovered and are described herein: Scatella praia, S. plaumanni, S. rara, Scatophila darrowae, S. dianneae, and S. prainha. To facilitate identification of the tribe and included genera and species, we have included diagnoses of these taxa and have also provided an annotated key to the Neotropical genera in Scatellini. We have also provided illustrations of structures of the male terminalia of all included species of the genus Scatophila.
\end{abstract}

KEY WORDS. Neotropical Region; shore flies; taxonomy.

In the Neotropical Region, the tribe Scatellini Wirth \& Stone, 1956 is biologically diverse (Mathis \& Zatwarnicki 1995), and many of the included species, perhaps a majority, are undescribed. This is particularly true of the Andean fauna. These observations are based on fieldwork in the Neotropics, especially in Andean countries, and subsequent recognition of numerous morphospecies. Although Scatellini are especially diverse in Neotropical countries with altitudinal relief, there is also considerable diversity elsewhere in the Neotropics, such as the fauna of Brazil, which is the subject of this paper. This review of Scatellini was prompted by recent field work in southern Brazil that is part of an overall survey of the shore flies of this biologically diverse country. An objective of the field work in 2009-2010 was to survey the shore-fly fauna from the state of Paraná and to a lesser degree from Santa Catarina and São Paulo and resulted in numerous specimens of Scatellini. We soon discovered that eight species were represented in the fauna and that six of these are undescribed. The purpose of this paper is to describe these new species within the context of a faunistic review of Scatellini from Brazil.

Characterization of Scatellini occurred relatively recently in the nomenclatural history of shore flies (WIRTH \& STONE 1956) and initially included some genera that have now been placed in Ephydrini (Wirth 1965, 1968, Cogan \& Wirth 1977, Cogan 1980, 1984). A more phylogenetically accurate classification of genera in Scatellini is presented in the world catalog of MATHIS $\&$ ZATWARNICKI (1995) and that classification is followed in this paper wherein the tribe is more fully diagnosed.

\section{MATERIAL AND METHODS}

The descriptive terminology, with the exceptions noted in Mathis (1986) and Mathis \& ZatwarNicki (1990a), follows that published in the Manual of Nearctic Diptera (McAlpine 1981). Because specimens of Scatellini are generally small, usually less than $3.0 \mathrm{~mm}$ in length, study and illustration of the male terminalia required use of a compound microscope. We have followed the terminology for most structures of the male terminalia that other workers in Ephydridae have used (see references in Mathis 1986, Mathis \& Zatwarnicki 1990a, b), such as surstylus. ZaTWARNICKI (1996) suggested that the pre- and postsurstylus correspond with the pre- and postgonostylus and that the subepandrial plate is the same as the medandrium. The terminology for structures of the male terminalia is provided in the legends. We use the term basal flagellomere for the large antennomere beyond the pedicel. We prefer this term over "first flagellomere" as there may be more than one flagellomere involved, and basal does not imply a number or numbers. We likewise do not use "postpedicel" (STUCKenberg 1999) for this antennomere because at least the multisegmented arista is beyond the pedicel in addition to the large antennomere, and postpedicel is thus ambiguous and lacking precision.

Dissections of male and female genitalia and descriptions were performed using the method of Clausen \& Cook (1971) and GRIMALDi (1987). Microforceps were used to remove abdomens, which were macerated in a potassium hydroxide solu-

2014 Sociedade Brasileira de Zoologia | www.sbzoologia.org.br | www.scielo.br/zool All content of the journal, except where identified, is licensed under a Creative Commons attribution-type BY-NC. 
tion. Cleared genitalia were rinsed in a weak solution of acetic acid and then transferred to glycerin for observation and illustration. If necessary for proper orientation, the specimen was transferred from glycerin to glycerin jelly. The glycerin jelly was heated, and the specimen appropriately oriented. After cooling, the embedded specimen in glycerin jelly became immobilized. The abdomen was placed in a plastic microvial filled with glycerin and attached to the pin supporting the remainder of the insect from which it was removed.

The new species descriptions are composite and not based solely on holotypes. Two head and two venational ratios used in the descriptions are based on three specimens (largest, smallest, and one other): Eye ratio: maximum width/maximum height; Gena-to-eye ratio: genal height (immediately below maximum eye height)/eye height; Costal vein ratio: the straight line distance between the apices of $\mathrm{R}_{2+3}$ and $\mathrm{R}_{4+5}$ /distance between the apices of $R_{1}$ and $R_{2+3}$; $M$ vein ratio: the straight line distance along vein $\mathrm{M}$ between crossveins $\mathrm{dm}$-cu and r-m/distance apicad of dm-cu.

Specimens for this study are in the Natural History Museum, London (BMNH); Universidade Federal do Paraná, Coleção Entomológica Padre Jesus Santiago Moure, Departamento de Zoologia, Curitiba, Paraná, Brazil (DZUP); Instituto Nacional de Pesquisas da Amazônia, Manaus, Amazonas, Brazil (INPA); Museu de Zoologia, Universidade de São Paulo, São Paulo, Brazil (MZUSP); and the National Museum of Natural History, Smithsonian Institution, Washington, D.C. (USNM).

\section{TAXONOMY}

\section{Scatellini Wirth \& Stone, 1956}

Scatellini Wirth \& Stone, 1956: 466. Type genus: Scatella RobineauDesvoidy, 1830. -Mathis \& Zatwarnicki, 1995: 254-288 [world catalog].

Diagnosis. Specimens of Scatellini may be distinguished from other Ephydridae by the following combination of character states: Head: Mesofrons subquadrate, slightly wider posteriorly, appearing dull, densely microtomentose or shiny with metallic luster; lacking interfrontal setae; usually 2 lateroclinate, fronto-orbital setae (most genera) or 1 (Limnellia Malloch, most Scatophila Becker). Antenna relatively short; arista essentially bare, macropubescent (most genera) or bearing long dorsal rays (Philotelma Becker). Face projected, setulose to moderately densely pilose, marginal setae usually larger; dorsum of interfoveal hump usually similar to rest of face, dark colored in a few species, not shiny; eye bare, usually as wide as high, nearly round to obliquely oval, generally oriented obliquely to plane of epistoma; gena short to high, usually bearing a genal seta (most genera) or lacking (Haloscatella Mathis, Lamproscatella Hendel, Philotelma, Thinoscatella Mathis); oral opening moderately large, gaping, usually concealing clypeus.
Thorax: Dorsocentral setae $2-3(0+2,1+2)$, some setae in some specimens weakly developed, the posteriormost seta displaced laterally from alignment of others; intrapostalar seta lacking or weakly developed; presutural supra-alar seta variable, subequal or larger than anterior notopleural seta [Scatella (Parascatella Cresson)] or greatly reduced, weakly developed (most genera); postsutural supra-alar seta often reduced or lacking; 2 notopleural setae, placement of posterior seta variable, usually at same level as anterior seta; proepisternum lacking setae but often with a few setulae; prosternum bare of setae or setulae; anepisternum bearing 1 large seta just dorsad of midheight along posterior margin, several smaller setulae may also be present; anepimeron, meron, and metapleuron bare of setae. Wing hyaline to conspicuously infuscate with white spots; costal vein extended to vein $\mathrm{M}$ (most genera) or to vein $\mathrm{R}_{4+5}$ (Scatophila); vein $\mathrm{R}_{2+3}$ usually long, terminating at approximately same distance from vein $\mathrm{R}_{4+5}$ as tip of vein $\mathrm{M}$ is from vein $\mathrm{R}_{4+5}$. Hindcoxal strap not setose; pulvilli normally developed; tarsal claws short, curved. Abdomen: Male with 5 visible abdominal tergites, tergite 5 distinctly trapezoidal or triangular; female with 6 , sometimes 7 , visible tergites, tergite 5 subtrapezoidal, not triangular. Male terminalia: Surstylus usually fused with ventral margin of epandrium and not evident (most genera) or evident as lobes, perhaps secondarily developed (Lamproscatella, Limnellia); aedeagus usually sclerotized (apparently basiphallus) (Amalopteryx Eaton, Haloscatella [other than New Zealand species], Lamproscatella, Limnellia, Scatella, Scatophila, Thinoscatella) or with a sclerotized basiphallus and a membranous distiphallus invested with short, sharp scales or scale-like thorns (some Haloscatella [species from New Zealand], Philotelma); ejaculatory apodeme lacking (Amalopteryx, Haloscatella, Lamproscatella, Limnellia, Philotelma, Scatophila, Thinoscatella) or present as an L-shaped, flattened (dorsoventrally) structure (Apulvillus Malloch, Neoscatella Malloch, Scatella, Synhoplos Lamb, Teichomyza Macquart); phallapodeme rudimentary, rodlike, lacking a keel (Amalopteryx, Haloscatella, Lamproscatella, Limnellia, Philotelma, Scatophila) or greatly reduced or lacking (Apulvillus, Neoscatella, Scatella, Synhoplos, Teichomyza); gonites and hypandrium fused forming a single structure ("gonal arch") (Amalopteryx, Haloscatella, Lamproscatella, Thinoscatella, Apulvillus, Neoscatella, Scatella, Synhoplos, Teichomyza, ground plan of Limnellia) or separated into medial sclerite "hypandrium" and lateral structures representing gonites (Philotelma, New Zealand Haloscatella, most Scatophila) or separated medioventrally into 2 lateral structures "gonites" (most Limnellia) (2 separate gonites are present also in some Scatophila (avida group), in which the "hypandrium" is reduced).

Discussion. As characterized here, the tribe Scatellini is monophyletic (Olafsson 1991), and some of the eight included genera (Amalopteryx, Haloscatella, Lamproscatella, Limnellia, Philotelma, Scatella [subgenera: Apulvillus, Neoscatella, Scatella, Synhoplos, Teichomyza], Scatophila, Thinoscatella) are found 
throughout the world in temperate and tropical zones. Worldwide there are over 245 species in the tribe (Mathis \& ZatWARNICKI 1995), and in the Neotropical Region there are records of four genera and nearly 70 species with a majority being classified in the genus Scatella and its included subgenera. Although largely undescribed, there is considerable species diversity at higher elevations associated with the Andes. We have collected specimens at localities above $5000 \mathrm{~m}$ in Colombia.

\section{Key to Neotropical genera and subgenera of Scatellini}

1. Costa short, extended to vein $\mathrm{R}_{4+5}$ (Figs 11-12) Scatophila Becker

$1^{\prime}$. Costa long, extended to vein M (Figs 8-10) .. 2

2. Lateroclinate fronto-orbital seta 1 ........... Limnellia Malloch

2 '. Lateroclinate fronto-orbital setae 2 3

3. Genal seta large, conspicuous. Wing usually with distinct to obscure pale spots (Scatella Robineau-Desvoidy) . 4

3'. Genal seta greatly reduced or lacking. Wing without pale spots Haloscatella Mathis

4. Postsutural supra-alar seta subequal in length to postalar seta Scatella (Parascatella Cresson)

4'. Postsutural supra-alar seta reduced, 1/2 length of postalar seta.

5. Dorsocentral setae $2(0+2)$, anterior seta postsutural ........ 6

5 '. Dorsocentral setae 2-3 $(1+1,1+2)$, anterior seta presutural... 7

6. Wing generally darkly infuscate, with evident pattern of white spots; dorsum of scutellum bare; setae of midcoxa short; male midfemur lacking row of setae ... Scatella (Scatella Robineau-Desvoidy), in part

6 '. Wing lightly infuscate, faintly brown, but lacking pattern of white spots; dorsum of scutellum setose, more so toward lateral margins; midcoxa with row of long setae along anteroventral surface; male midfemur with row of 7-10 long, stout setae near middle of posteroventral surface, setae longer than width of femur

Scatella (Teichomyza Macquart)

7. Wing micropterous, subequal to length of hindbasitarsus; pedicel with spine-like, dorsal seta subequal to length of arista Scatella (Synhoplos Lamb)

7 '. Wing stenopterous to macropterous, if reduced, much longer than length of hindbasitarsus; seta of pedicel if present much shorter, not more than $1 / 2$ length of arista .......... 8

8. Only 1 well-developed acrostichal seta present, inserted at suture. Scatella (Neoscatella Malloch)

8'. Acrostichal setae generally weak, short, continuing in a postsutural row to base of scutellum

Scatella (Scatella Robineau-Desvoidy), in part

\section{Limnellia Malloch, 1925}

Limnellia Malloch, 1925: 331. Type species: Limnellia maculipennis Malloch, 1925, original designation. -Mathis, 1978: 250-293 [revision of Nearctic species]. -Mathis \& Zatwarnicki, 1995: 258-261 [world catalog].

Eustigoptera Cresson, 1930: 126. Type species: Notiphila quadrata Fallén, 1813, original designation. -Cresson, 1935: 362 [synonymy].

Stictoscatella Collin, 1930: 133. Type species: Notiphila quadrata Fallén, 1813, original designation. -Cresson, 1935: 362 [synonymy].

Stranditella Duda, 1942: 30 (as a subgenus of Lamproscatella). Type species: Notiphila quadrata Fallén, 1813, original designation. -Dahl, 1959: 126 [synonymy].

Diagnosis. Limnellia is distinguished from other genera of the tribe Scatellini by the following combination of characters: small to moderately small shore flies, body length $1.25-2.50 \mathrm{~mm}$; mostly dark brown to black, microtomentose to bare, shiny, frequently with cinereous guttate and vittate maculae; wing maculate, generally dark with white spots. Head: Mesofrons distinct from duller parafrons, sometimes subshiny; 1 lateroclinate, fronto-orbital seta; medial and lateral vertical setae both well developed; paravertical setae either reduced or absent; ocelli arranged in isosceles or equilateral triangle. Arista at most macropubescent. Face with antennal grooves shallow; interfoveal carina not projected or creased dorsally; facial setae mostly small, hair-like. Eye nearly round. Gena relatively short, bearing 1 welldeveloped seta. Thorax: Acrostichal setae uniform in size, small, arranged in 2 rows that extend to base of scutellum; $2(0+2)$ dorsocentral setae; supra-alar seta either reduced or lacking; disc of scutellum bare; 2 lateral scutellar setae. Wing maculate, mostly dark brown with white, generally guttate markings; costa long, extended to vein M. Abdomen: Tergites black, becoming shiny and polished posteriorly. Male terminalia: Epandrium a closed plate around cercal cavity, bearing articulated surstyli on anterior margin; gonites elongate with broad base, bearing setae on ventral portion; phallapodeme in lateral view nearly straight or deflected medially; dorsal aedeagal opening with a fold along ventral margin; aedeagus without distiphallus; ejaculatory apodeme usually present, small.

Discussion. Worldwide, Limnellia includes 22 species (MATHIS \& ZatWARNicki 1995) that occur in most temperate regions of the world or at higher elevations in subtropical and tropical zones.

Although now stable, the early nomenclatural history of Limnellia reflects the lack of communications among workers on the genus and our very fragmentary knowledge about these shore flies on a world basis. MaLLoch (1925) first described Limnellia from a female specimen collected in Sydney, Australia. Just five years later Cresson (1930) and Collin (1930), in separate but coincidental publications, redescribed the genus as Eustigoptera and Stictoscatella, respectively. Both Cresson and 
Collin based their genus-group names on the same generitype, Notiphila quadrata Fallén, 1813. Although Fallén's species was originally known only from Scandinavia, it is now known to be Holarctic in distribution (Mathis 1978, Mathis \& ZatwarNicKI 1995) but is obviously quite disjunct from the southeastern coast of Australia where its congener, which is the generitype of Limnellia, is found. Duda (1942), in an unusual paper from the standpoint of nomenclature, redescribed Limnellia yet again, this time as the subgenus Stranditella of the genus Lamproscatella Hendel. Duda also based Stranditella on the generitype, Notiphila quadrata. Duda's paper is unconventional in having most of the new genus-group and several of the included new species names as patronyms, all based on his colleague, Embrik Strand (1876-1953).

\section{Limnellia itatiaia Mathis, 1980}

Limnellia itatiaia Mathis, 1980: 24 [Brazil. Rio de Janeiro: Serra de Itatiaia $\left(22^{\circ} 28.6^{\prime} \mathrm{S}, 44^{\circ} 37.3^{\prime} \mathrm{W}\right)$; HT o', USNM (76066)]. Mathis \& Zatwarnicki, 1995: 259 [world catalog].

Diagnosis. This species is distinguished from related congeners by the following combination of characters: Small shore flies, body length of allotype $1.72 \mathrm{~mm}$ (abdomen of holotype removed before it was measured). Head: Head ratio 0.69. Frons mostly dark golden brown to blackish brown with faint metallic luster; parafrons wedge-shaped anteriorly, coloration gray to brownish gray; narrowly gray colored also along posterolateral margins of mesofrons. Face grayish to brownish, thin stripe along oral margin and to a lesser extent antennal fovea distinctly impressed but shallow. Eye ratio 0.91; gena-to-eye ratio 0.08. Thorax: Wing ratio 0.47; costal vein ratio 0.22 ; $\mathrm{M}$ vein ratio 0.72 ; maculation pattern of wing as follows: cell $r_{1}$ with 4-5 white spots, if apical one present not as evident; cell $r_{3}$ with 4 white spots, each well developed and evenly spaced along cell; cell $r_{5}$ with 5-6 poorly defined white spots, each small, apical ones frequently abutting; discal cell with 2-3 white spots, apical one better developed; cell $\mathrm{m}_{2}$ with 2 white spots; cell $\mathrm{m}_{4}$ with $2-3$ white areas, generally guttate. Halter blackish. Legs entirely dark, blackish brown, unicolorous. Abdomen: Male terminalia as follows: Epandrium higher than wide in posterior view, rounded dorsally, more or less truncate ventrally; surstylus subtriangular in posterior view, ventrolateral margins emarginated, generally setose; aedeagus in lateral view longer than wide, with shallowly V-shaped notch along dorsum; phallapodeme attached to posterior portion of aedeagus and extended ventrally.

Specimens examined from Brazil. Minas Gerais: Ouro Preto $\left(20^{\circ} 23.1^{\prime} \mathrm{S}, 43^{\circ} 30.2^{\prime} \mathrm{W}\right), 12-13$ Apr 1968 , F.C. do Val leg. (10'; MZUSP); Sapucai-Mirim, Cidade Azul (22 $44.8^{\prime} \mathrm{S}, 45^{\circ} 44.6^{\prime} \mathrm{W}$; 1400 m), 7 Nov 1953, M. Kuhlman, L. Travassos leg. (1o; MZUSP). Rio de Janeiro: Serra de Itatiaia $\left(22^{\circ} 28.6^{\prime} \mathrm{S}, 44^{\circ} 37.3^{\prime} \mathrm{W} ; 2180 \mathrm{~m}\right)$, 21 Feb 1922, E.G. Holt leg. (10; holotype; USNM).

Distribution. Neotropical: Brazil (Minas Gerais, Rio de Janeiro).

\section{Scatella Robineau-Desvoidy, 1830}

Scatella Robineau-Desvoidy, 1830: 801. Type species: Scatella buccata Robineau-Desvoidy, 1830 (= Ephydra stagnalis Fallén, 1813), designated by Coquillett, 1910: 603. -Wirth, 1968: 24-26 [Neotropical catalog]. -Blair \& Foote, 1984: 1336-1339 [resource partitioning of sympatric species]. -Mathis \& Zatwarnicki, 1995: 262-281 [world catalog].

Diagnosis. Scatella is distinguished from other genera of the tribe Scatellini by the following combination of characters: Minute to small shore flies, body length 0.80-3.00 mm. Head: Frons dull usually with distinct, subshiny to shiny mesofrons; 2 lateroclinate fronto-orbital seta. Antenna short, dark colored; pedicel with strong seta ventrally; basal flagellomere round; arista macropubescent to at most bearing short, hair-like, dorsal branches. Face moderately protuberant, uniformly sclerotized, lacking processes; facial setae conspicuous, usually 1-2 dorsoclinate setae, 4-8 setae on the oral margin. Eye nearly round. Gena short to moderately high; maxillary palpus elongate, mostly dark, exceptionally yellow. Thorax: Mesonotum generally dark colored, microtomentose, density of microtomentum varying, generally unicolorous or with longitudinal stripes, not conspicuously multicolored with pattern of bands and/or spots; dorsocentral setae usually $2(0+2)$, sometimes $3(1+2$, Neoscatella); scutellum flat, disc bare, bearing 2 pairs of marginal setae; pleural region generally gray, paler than mesonotum. Wing faintly to conspicuously infuscate with white spots distributed over much of wing, but exceptionally within cell $\mathrm{r}_{1}$; costa long, extended to vein $\mathrm{M}$; wings reduced in a few species; legs typical, usually without distinct setae (ventral row of spinulae on midtibiae of males of some species); color of tarsi variable; stem of halter short, head oval, white. Abdomen: Tergites gray to brown, microtomentose, sometimes with lighter posterior margins, or mostly shiny, blackish brown. Male terminalia: Epandrium a closed plate, rarely separated anteriorly; cerci completely round; gonal arch divided ventrally, in most cases separated into 3 parts: 2 lateral gonites and a ventral bandlike neohypandrium that may be reduced; gonites elongate, sharply terminated, sometimes bearing setae on dorsal margin of anterior portion; hypandrium as a more or less sinuous band; phallapodeme reduced; ejaculatory apodeme large, band-like, wide at connection with aedeagus; aedeagus shoeshaped in lateral view, in most species bearing narrow, un- or paired sinuous ventral process that originates from ventral side of distal aedeagal margin.

Discussion. Although there are slight and subtle differences in the conformation of structures of the male terminalia of Scatella, they are not as evident, for example, as in the genera Limnellia or Scatophila, and we have not generally relied on them in this paper. Oft times the shape of the male sternites, especially sternites four and five, are more diagnostic (Olafsson 1991). 


\section{Subgenus Neoscatella Malloch, 1933}

Neoscatella Malloch, 1933: 9 (as a genus). Type species: Neoscatella atra Malloch, 1933, original designation. Sturtevant \& Wheeler, 1954: 178 [revised status]. -Mathis \& Zatwarnicki, 1995: 263-268 [world catalog].

Strandella Duda, 1942: 30 (as a subgenus of Scatella). Type species: Scatella silacea Loew, 1860, original designation. -Dahl, 1959: 119 [synonymy].

Diagnosis. The subgenus Neoscatella is distinguished from other subgenera of the genus Scatella by the following combination of characters: Head: Pedicel seta, if present, short, not more than 1/2 length of arista. Thorax: Acrostichal seta usually 1 , presutural or sutural, some species only bearing setulae; dorsocentral setae $3(1+2)$ with anterior seta presutural or sutural; postsutural supra-alar seta reduced, $1 / 2$ length of postalar seta; dorsum of scutellum bare. Wing generally lightly to darkly infuscate, usually with evident pattern of white spots. Setae of midcoxa short; male midfemur lacking row of setae; pulvilli evident, normally developed; tarsal claws of normal size.

Discussion. Although the species groups that have been recognized within Neoscatella (MATHIs \& WIRTH 1981) are likely monophyletic (bicolor group, immaculata group, austrina group), the monophyly of the subgenus remains questionable. We suspect that the Neotropical species now placed in the subgenus Neoscatella (S. curtipennis (Becker), S. furens Cresson, Scatella gestiens Cresson, $S$. gregaria Cresson) do not form a monophyletic group with $S$. (Neoscatella) atra (Malloch), the type species of this subgenus.

There are now 35 species in this subgenus (Mathis \& ZatWARNICKI 1995) with the vast majority occurring in the Australasian and Oceanian Regions. In the Brazilian fauna, we have discovered a single species, which is described below.

\section{Scatella (Neoscatella) praia sp. nov.}

Figs $1-3,8$

Diagnosis. This species is distinguished from related congeners by the following combination of characters: Small to moderately small shore flies, body length 1.90-2.35 mm; general coloration brown. Head (Figs 1-3): Mesofrons and frontoorbits mostly microtomentose, faintly subshiny, brown; parafrons blackish gray. Basal flagellomere blackish brown apicodorsally, yellowish brown basoventrally. Face whitish gray to silvery gray. Gena short, height less than $1 / 3$ eye height; genato-eye ratio 0.26-0.29. Thorax: Mesonotum mostly brown, partially subshiny; postpronotum whitish gray; both notopleural setae inserted at about same level. Wing (Fig. 8) with white spots moderately conspicuous, cell $\mathrm{R}_{2+3}$ with 1 white spot; cell $\mathrm{R}_{4+5}$ with 2 spots, wing infuscate and with several pale spots; costal vein ratio 0.17-0.19; $\mathrm{M}$ vein ratio 0.62-0.69. Legs black; coxae, femora, and tibiae invested with gray microtomentum, similar to that of pleural area; tarsi black. Abdomen: Length of male tergites 2-3 about equal, length of tergite 4 conspicuously longer, subequal to tergite 5 ; tergite 4 brown anteriorly, gray posteriorly; tergite 5 of male mostly brown.

Type material. The holotype male is labeled "BRAZIL. Paraná: Antonina $\left(25^{\circ} 28.4^{\prime} \mathrm{S}, 48^{\circ} 40.9^{\prime} \mathrm{W}\right.$; mangal), 9 Apr 2010 , D. \& W. N. Mathis/HOLOTYPE ơ Scatella praia Mathis, Marinoni \& Costa DZUP [red]." The holotype is double mounted (minuten in a block of plastic), is in excellent condition, and is deposited in DZUP. Six paratypes (60", 2q; DZUP, USNM) bear the same locality data as the holotype but with variable days (3 Feb-14 Nov 2010). Other paratypes are as follows: BraziL, Paraná: Antonina ( $25^{\circ} 27.1^{\prime} \mathrm{S}, 48^{\circ} 41.1^{\prime} \mathrm{W}$; Ponta da Pita; beach), 3-15 Feb 2010, D. and W.N. Mathis leg. (40', 4; DZUP, USNM).

Type locality. Brazil, Paraná: Antonina $\left(25^{\circ} 28.4^{\prime} \mathrm{S}\right.$, $48^{\circ} 40.9^{\prime} \mathrm{W}$; beach/mangal).

Natural history. We collected adults of this species on maritime beaches, especially where there was vegetation, such as the mangal at the type locality.

Distribution. Neotropical: Brazil (Paraná).

Etymology. The species epithet, praia, is the Portuguese word for beach, the habitat where this species is found in southern Brazil. The species epithet is a noun in apposition.

Remarks. This species is smaller than most Neotropical species of the subgenus Neoscatella and differs from them in being smaller in length, having a whitish to silvery gray face, and having a normally developed wing. This is the first and thus far the only species of this subgenus known from Brazil, although the lengthy maritime beaches of Brazil have not been well sampled for shore flies and other species may yet be discovered.

\section{Subgenus Scatella Robineau-Desvoidy, 1830}

Scatella Robineau-Desvoidy, 1830: 801 (as a genus). Type species: Scatella buccata Robineau-Desvoidy, 1830 (= Ephydra stagnalis Fallén, 1813), designated by Coquillett, 1910: 603.

Trixostomus Rondani, 1856: 130 (as a genus). Type species: Ephydra stagnalis Fallén, 1813, original designation. -Becker, 1905: 210 [synonymy].

Diagnosis. The subgenus Scatella is distinguished from other subgenera of the genus Scatella by the following combination of characters: Head: Setae of pedicel, if present, short, not more than $1 / 2$ length of arista. Thorax: Dorsocentral setae 2, both postsutural $(0+2)$; 1 prominent, presutural acrostichal seta; postsutural supra-alar seta reduced, $1 / 2$ length of postalar seta; scutellar disc bare. Wing generally infuscate with evident pattern of white spots. Setae of midcoxa short; male midfemur lacking row of setae; pulvilli evident, normally developed, tarsal claws normally developed, not conspicuously elongate.

\section{Key to species of subgenus Scatella from Brazil}

1. Large specimens (> $2.50 \mathrm{~mm}$ ); face distinctly bicolored (Figs 6-7) ............................................... S. plaumanni sp. nov.

$1^{\prime}$. Smaller specimens $(<2.00 \mathrm{~mm})$, face mostly unicolorous (Figs 4-5) ..................................................................... 2 


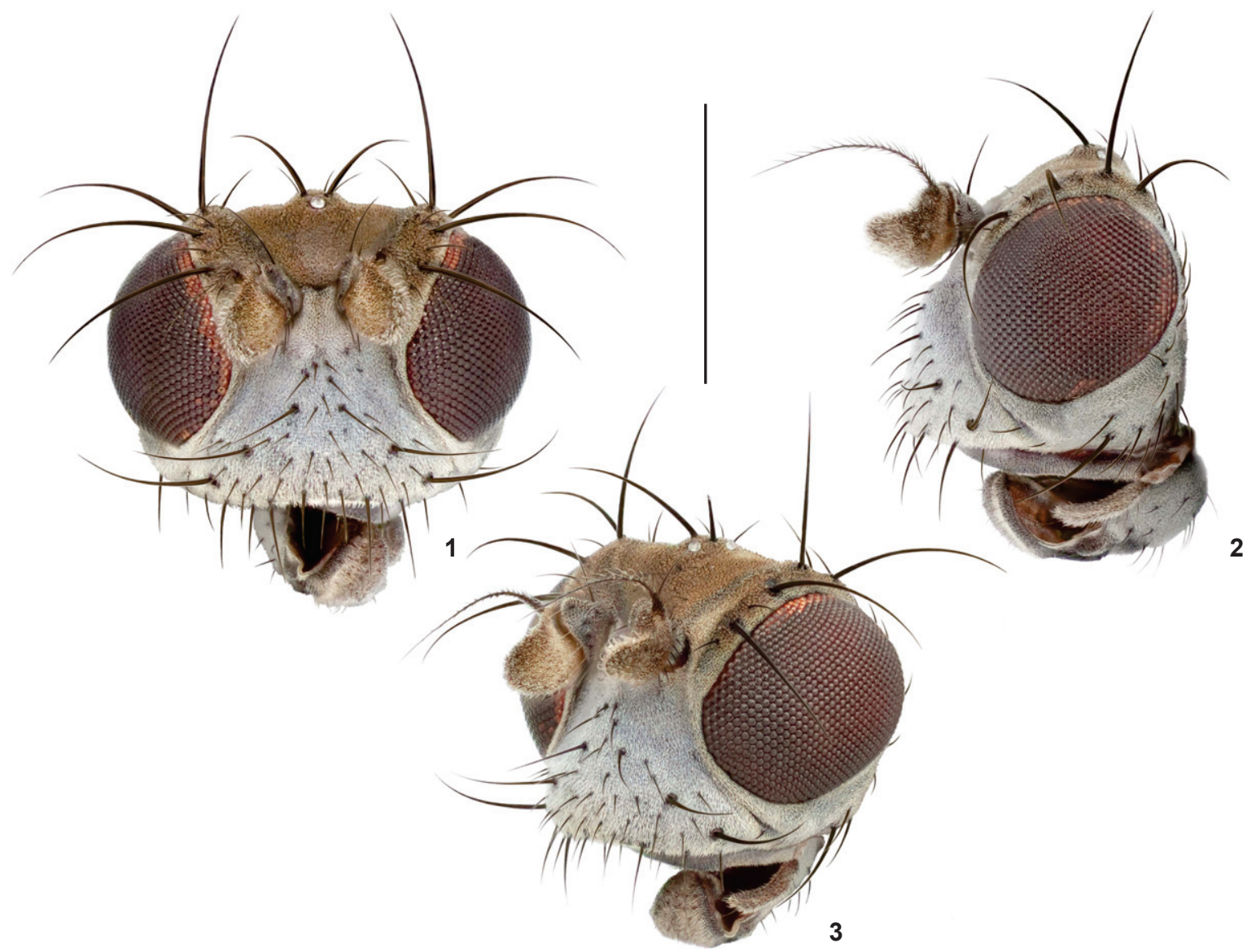

Figures 1-3. Scatella (Neoscatella) praia sp. nov., Brazil, Paraná: Antonina: (1) head, anterior view; (2) same, lateral view; (3) same, oblique view. Scale bar: $0.5 \mathrm{~mm}$.

2. Basal flagellomere black; wing with white spots moderately conspicuous, cell $\mathrm{R}_{2+3}$ with 1 white spot, cell $\mathrm{R}_{4+5}$ with 2 spots S. obscura Williston

2'. Basal flagellomere mostly yellow, only dorsal margin darkened; wing with white spots very conspicuous, cell $\mathrm{R}_{2+3}$ with 2 white spots, cell $\mathrm{R}_{4+5}$ with 3 spots (Fig. 9) S. rara sp. nov.

\section{Scatella (Scatella) obscura Williston, 1896}

Scatella obscura Williston, 1896: 403 [West Indies. St. Vincent $\left(13^{\circ} 10^{\prime} \mathrm{N}, 61^{\circ} 14^{\prime} \mathrm{W}\right)$; LT $0^{\prime \prime}$ (designated by Mathis \& Edmiston, 1991: 836-837), BMNH]. -Wirth 1968: 26 [Neotropical catalog]. -Lizarralde de Grosso, 1989: 61 [list, Argentina]. Mathis \& Edmiston, 1991: 836-837 [review of Williston's St. Vincent species]. -Mathis \& Zatwarnicki, 1995: 274 [world catalog]. -Mathis, 1997: 67-68 [review, Belize].

Scatella laetifica Cresson, 1934: 217 [Argentina. Buenos Aires; HT ơ, BMNH]. -Cresson, 1935: 365 [synonymy].
Diagnosis. This species is distinguished from related congeners by the following combination of characters: Small to moderately small shore flies, body length 1.65-2.10 mm; general coloration brown. Head: Mesofrons partially microtomentose, subshiny; basal flagellomere black; gena low, height less than $1 / 3$ eye height. Gena short, gena-to-eye ratio 0.10-0.11. Thorax: Both notopleural setae inserted at about same level; wing with white spots moderately conspicuous, cell $\mathrm{R}_{2+3}$ with 1 white spot, cell $R_{4+5}$ with 2 spots, wing infuscate and with several pale spots; costal vein ratio $0.18-0.19$; $M$ vein ratio 0.58 0.60 . Abdomen: Length of male tergites $2-3$ about equal; length of tergite 4 conspicuously longer, subequal to tergite 5 .

Specimens examined from BraziL, Maranhão: Carolina, Rio Lages $\left(07^{\circ} 19.8^{\prime} \mathrm{S}, 47^{\circ} 28.1^{\prime} \mathrm{W}\right)$, Dec 2001, F.L. Oliveira, J.A. Rafael, J. Vidal leg. (1요 INPA). Pará: Santarém $\left(0^{\circ} 57.4^{\prime} \mathrm{S}, 46^{\circ} 59^{\prime} \mathrm{W}\right)$, Jun

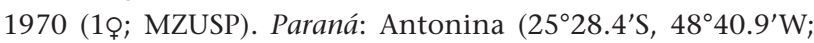
beach/mangal), 4 Feb 2010, D. and W.N. Mathis leg. (10', 1\%;

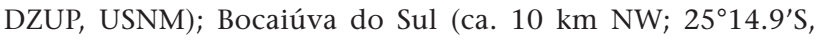
$\left.49^{\circ} 08.9^{\prime} \mathrm{W} ; 890 \mathrm{~m}\right), 4$ Nov 2010, D. and W.N. Mathis leg. (20'; 
DZUP, USNM); Castro (Parque Lacustre; $24^{\circ} 47.4^{\prime} \mathrm{S}, 50^{\circ} 0.3^{\prime} \mathrm{W}$; 990 m), 24-25 Dec 2009, D. and W.N. Mathis leg. (80", 6o; DZUP,

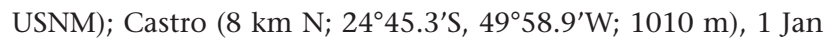
2010, D. and W.N. Mathis leg. (30', 3o; DZUP, USNM); Matinhos

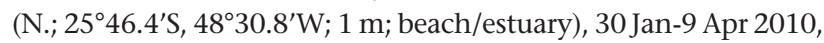
D. and W.N. Mathis leg. (30', 4\%; DZUP, USNM); Matinhos (Rio da Onça; $\left.25^{\circ} 47.4^{\prime} \mathrm{S}, 48^{\circ} 31.6^{\prime} \mathrm{W} ; 3 \mathrm{~m}\right), 12$ Nov 2010, D. and W.N. Mathis leg. (40', 1\%; DZUP, USNM); Paranaguá (2530.8'S, $\left.48^{\circ} 29.9^{\prime} \mathrm{W} ; 3 \mathrm{~m}\right), 23 \mathrm{Jan}$ 2010, D. and W.N. Mathis leg. (10'; DZUP, USNM); Curitiba, Parque Iguaçu ( $\left.25^{\circ} 33.4^{\prime} \mathrm{S}, 49^{\circ} 13.6^{\prime} \mathrm{W} ; 880 \mathrm{~m}\right)$, 26 Jan-9 Nov 2010, D. and W.N. Mathis leg. (140", 6\%; DZUP,

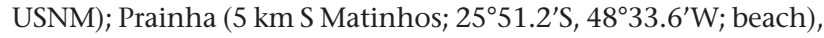
15 Nov 2010, D. and W.N. Mathis leg. (80', 2Q; DZUP, USNM). Rio de Janeiro: Gávea $\left(22^{\circ} 59.2^{\prime} \mathrm{S}, 43^{\circ} 14.7^{\prime} \mathrm{W}\right), 29$ Jun 1937, H. Souza Lopes leg. (10'; MZUSP). Santa Catarina: Barra Velha

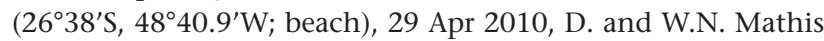

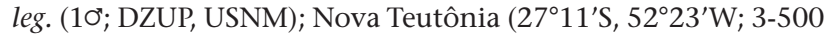
m), Jul-Oct 1970, 1971, F. Plaumann leg. (20", 8@; MZUSP). São Paulo: Ubatuba, Praia do Estaleiro ( $23^{\circ} 20.5^{\prime} \mathrm{S}, 44^{\circ} 53^{\prime} \mathrm{W}$; beach), 29-30 Mar 2010, D. and W.N. Mathis leg. (40', 4\%; DZUP, USNM).

Distribution. Nearctic: United States (Florida). Neotropical: Argentina, Bahamas, Brazil (Maranhão, Pará, Paraná, Rio de Janeiro, Santa Catarina, São Paulo), Costa Rica, Ecuador, El Salvador, Panamá, Paraguay, West Indies (Cuba, Dominica, Dominican Republic, Grenada, Jamaica, Puerto Rico, St. Vincent).

Remarks. This is the most widespread species of Scatellini in Brazil. As noted in the "Distribution," this species occurs widely in the New World, especially in tropical zones.

\section{Scatella (Scatella) rara sp. nov. Figs 4-5, 9}

Diagnosis. This species is distinguished from related congeners by the following combination of characters: Small to moderately small shore flies, body length 1.50-2.00 mm; general coloration brown. Head (Figs 4-5): Mesofrons partially microtomentose, subshiny. Basal flagellomere mostly yellow, usually only dorsal margin darkened. Face silvery gray. Gena very low, height less than $1 / 3$ eye height; genal seta evident; gena-to-eye ratio 0.10-0.12. Thorax: Mesonotum dark brown, partially subshiny; postpronotum silvery gray; both notopleural setae inserted at about same level. Wing (Fig. 9) with white spots very conspicuous, cell $\mathrm{R}_{2+3}$ with 2 white spots, cell $\mathrm{R}_{4+5}$ with 3 spots; costal vein ratio $0.18-0.20$; $\mathrm{M}$ vein ratio 0.58 0.62. Abdomen: Mostly shiny black; length of male tergites 2-4 about equal; tergite 5 longer than combined length of tergites 3 and 4; male tergite 5 trapezoidal from a dorsal view, somewhat truncate along posterior margin.

Type material. The holotype male of Scatella rara is labeled “Brazil. Paraná: Iguaçu $\left(25^{\circ} 33.4^{\prime} \mathrm{S}, 49^{\circ} 13.6^{\prime} \mathrm{W} ; 880 \mathrm{~m}\right)$, 16 Jan 2010, D. \& W. N. Mathis/HOLOTYPE ơ Scataella rara Mathis, Marinoni \& Costa DZUP [red]." The holotype is double mounted (minuten in a block of plastic), is in excellent condi- tion, and is deposited in DZUP. Five paratypes (20', 3o; DZUP, USNM) bear the same locality data as the holotype but with dates from 2-4 Nov 2010.

Type locality. Brazil, Paraná: Curitiba (Parque Iguaçu, $25^{\circ} 33.4^{\prime} \mathrm{S}, 49^{\circ} 13.6^{\prime} \mathrm{W} ; 880 \mathrm{~m}$ ). Parque Iguaçu is an extensive public wetlands with several ponds and some slow flowing lotic aquatic systems in the southern portion of the municipality of Curitiba. The primary site where we sampled the local shorefly fauna was just north of a zoo. Livestock forage at this locality, which is largely open pastures, although there are some wooded areas where the substrate is in deep shade, is mostly bare, and is often wet if not muddy. Mosquitoes abound in the wooded areas.

Distribution. Neotropical: Brazil (Paraná).

Etymology. The species epithet, rara, is the Portuguese word for rare and refers to the apparent scarcity of this species.

Remarks. The shiny, black abdomen and more pronounced spotting in the wing pattern distinguish this species from congeners, especially $S$. obscura, which occurs microsympatrically and is often more abundant at the same local. On average, specimens are also slightly larger than those of $S$. obscura.

This species may be more abundant in the austral spring from November through January. Most specimens were collected in November, and after January, no further specimens were collected despite repeated attempts to find and sample them.

Most specimens collected in November were captured by sweeping the surface of accumulated piles of partially decomposing water lettuce along the sides of a small spillway. The surrounding area was thoroughly sampled without encountering specimens elsewhere.

\section{The triseta group}

Diagnosis. Species of the triseta group are distinguished by their size usually larger than other Scatella, body length 2.20$4.00 \mathrm{~mm}$.

Description. Head: Ocelli arranged in an equilateral triangle; dorsalmost postocular setae weakly developed, subequal to pseudopostocellar setae; arista longer than combined length of scape, pedicel, and basal flagellomere, micropectinate dorsally; facial setae extended from interfoveal hump to posteroventral corner of face, well developed, subequal to length of setae along oral margin, often semiporrect. Thorax: Acrostichal setae small, hairlike, lacking distinctly larger pair at transverse suture; dorsocentral setae $3(1+2)$; supra-alar seta rudimentary, at most $1 / 2$ length of postalar seta; scutellum with 2 lateral setae; costal margin with interspersed, slightly larger setulae, length of these not more than width of costal vein. Abdomen: Phallapodeme flattened dorsoventrally; surstylus fused indistinguishably with venter of epandrium.

Discussion. Mathis \& Shewell (1978) first recognized and characterized the triseta group, which is in the nominate subgenus Scatella and which then included three Nearctic species that occur in the western United States and Canada. They also docu- 


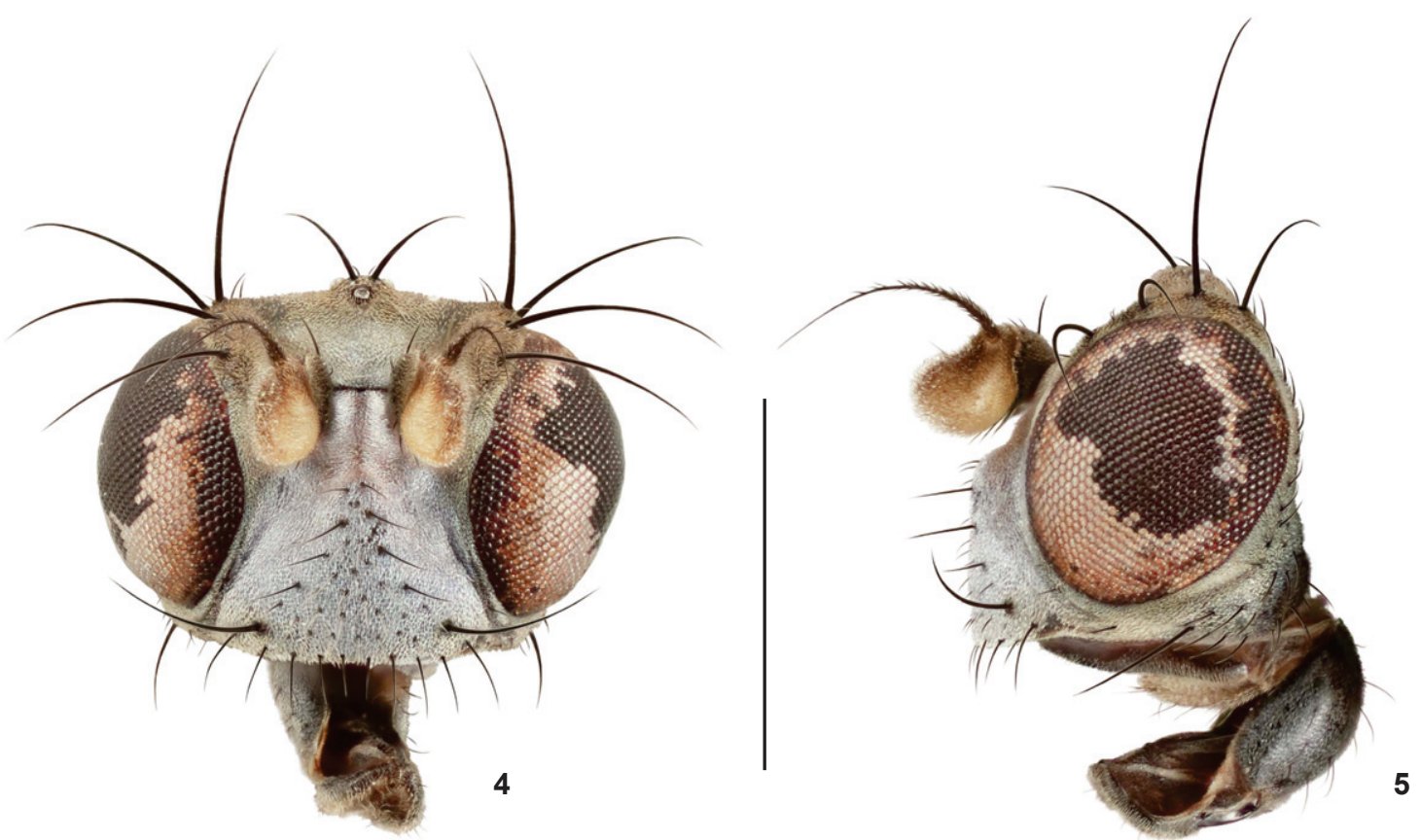

Figures 4-5. Scatella (Scatella) rara sp. nov., Brazil, Paraná: Curitiba, (Parque Iguaçu): (4) head, anterior view; (5) same, lateral view. Scale bar: $0.5 \mathrm{~mm}$.

mented the monophyly of the species group, which is based on two synapomorphies (facial setae distinctly curved dorsally; acrostichal setulae usually lacking posterior of enlarged, sutural pair). Mathis \& Zumbado (2005) described the first Neotropical species of this species group, $S$. savegre, from specimens collected in Costa Rica, and herein a second species is described.

\section{Scatella (Scatella) plaumanni sp. nov.}

Figs 6-7, 10

Diagnosis. This species is distinguished from congeners, especially those of the triseta group, by the following combination of characters: Moderately small to medium-sized shore flies, body length 2.70-2.85 mm; generally dark colored. Head (Figs 67): Mesofrons mostly subshiny, dark brown, mostly bare of microtomentum except for moderately narrow area immediately anterior of anteromedial ocellus and extended to frontal suture; parafrons and fronto-orbits dark brown, microtomentose; ocelli arranged in almost equilateral triangle with distance between posterior pair slightly greater than that between either posterior ocellus and anteromedial ocellus. Face bicolored, between antennae and dorsum of interfoveal hump dark brown to brown, contrasted with more grayish brown ventral portion, lateral margin of facial prominence faintly bluish gray. Gena concolorous with lateral portions of face, slightly more than $1 /$ 4 eye height; gena-to-eye ratio 0.19-0.21; eye almost round, slightly higher than wide. Thorax: Mesonotum mostly dark brown, subshiny, thinly microtomentose, becoming lighter brown and more microtomentose laterally; scutellum weakly convex; postpronotum very light tan to gray; notopleuron brown, densely microtomentose; pleural area generally gray, densely microtomentose, except for brown posterodorsal $1 / 3$ of anepisternum and faintly brown area at ventral margin of anepisternum. Wing of male (Fig. 10) mostly uniformly lightly to moderately brown, with white spots faint but evident (middle of cell $\mathrm{r}_{2+3} ; 2$ in cell $\mathrm{r}_{4+5} ; 1$ subapical in cell $\mathrm{dm}$ ) but no apical, brown linear spot at apex of vein $\mathrm{R}_{2+3}$ and $\mathrm{R}_{4+5}$; wing of female similar to male; costal vein ratio $0.13-0.16$; $\mathrm{M}$ vein ratio 0.52 0.56 . Legs with femora gray to grayish brown, becoming slightly darker posteroapically; hindfemora shiny blackish brown posteriorly; tibiae blackish brown to black; tarsi black. Abdomen: Dorsum of tergites dark brown, subshiny; basal tergites slightly lighter, especially laterally; ventral portion of tergites becoming gray. Structures of male terminalia not described or illustrated as they are similar to other congeners of the triseta group.

Type material. The holotype male of Scatella plaumanni is labeled “[Brazil.] SÃO PAULO[:] Cubatão [2353.7'S, $46^{\circ} 25.6^{\prime} \mathrm{W}$ ] Pereira[,] Martinez[,] Wernen[,] [M. A. V.] d'Andretta 15-11-55 [15 Dec 1955][names of collectors and date of collection handwritten]/HOLOTYPE ơ Scatella plaumanni Mathis, Marinoni \& Costa DZUP [red]." The holotype is double mounted (minuten in a block of pith), is in good condition (some setae missing or misoriented), and is deposited in DZUP. Paratypes are as follows: BraziL, Santa catarina: Nova Teutônia (27 $7^{\circ} 11^{\prime} \mathrm{S}, 52^{\circ} 23^{\prime} \mathrm{W}$; 3-500 m), Jul-Oct 1970, F. Plaumann leg. (50", 6\%; MZUSP, USNM). 

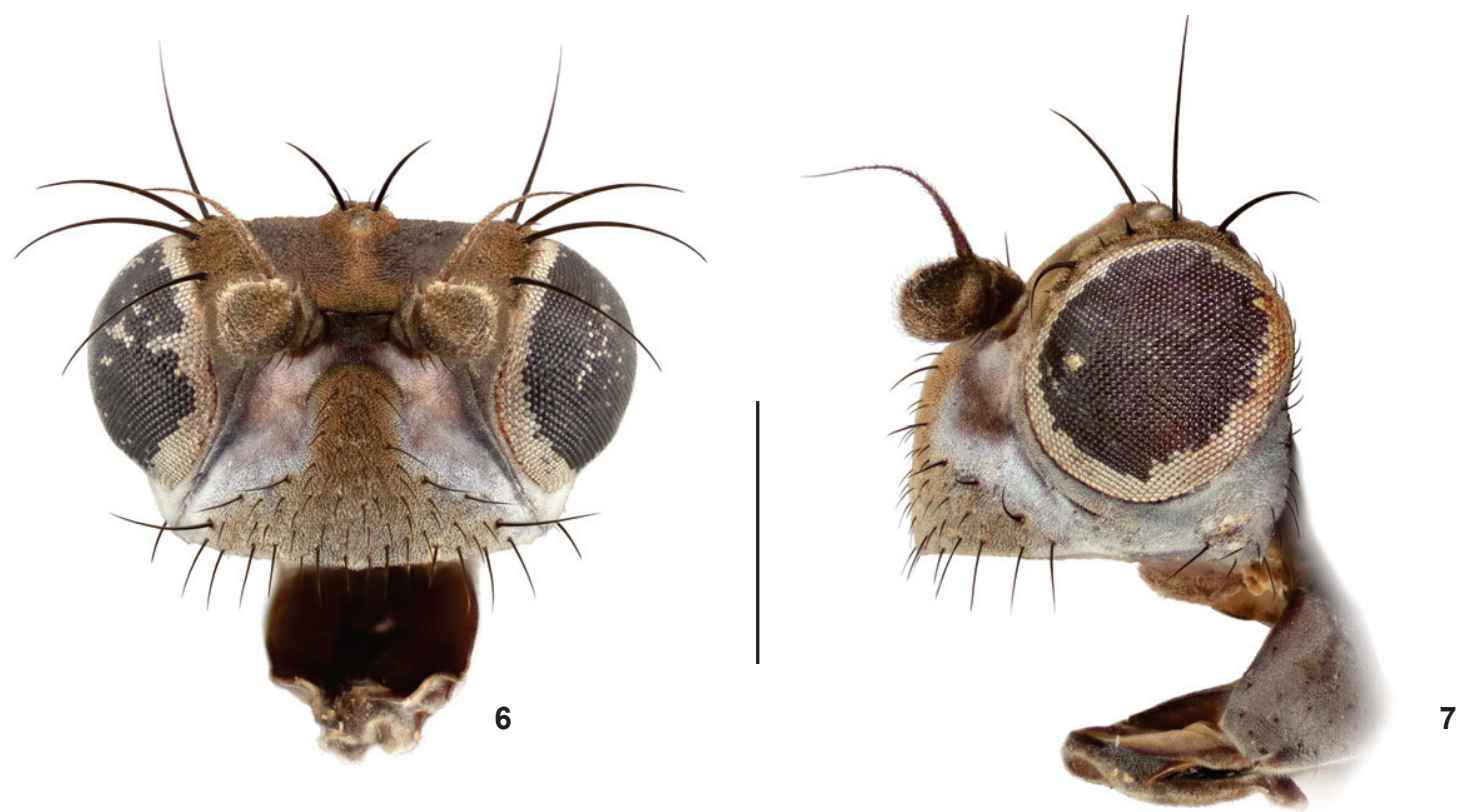

Figures 6-7. Scatella (Scatella) plaumanni sp. nov., Brazil, Santa Catarina: Nova Teutônia: (6) head, anterior view; (7) same, lateral view. Scale bar: $0.5 \mathrm{~mm}$.

Type locality. Brazil, São Paulo: Cubatão (2353.7'S, $\left.46^{\circ} 25.6^{\prime} \mathrm{W}\right)$.

Distribution. Neotropical: Brazil (Santa Catarina, São Paulo).

Etymology. The species epithet, plaumanni, is a Latin genitive patronym to honor Fritz Plaumann (deceased), collector extraordinaire, whose carefully prepared specimens have contributed significantly to the study of Brazil's insect biodiversity.

Remarks. This species substantially extends the range of the triseta group and is somewhat disjunct from the other included species. We suspect, however, that this apparent disjunction will disappear once we have a better sampling of shore flies from localities between outliers of the disjunction.

\section{Scatophila Becker, 1896}

Scatophila Becker, 1896: 237. Type species: Ephydra caviceps Stenhammar, 1844, original designation. -Wirth, 1968: 27 28 [Neotropical catalog]. -Zatwarnicki, 1987: 277-298 [checklist]. -Zatwarnicki \& Mathis, 1994: 351-370 [classification, phylogeny]. -Mathis \& Zatwarnicki, 1995: 281-287 [world catalog].

Centromeromyia Frey, 1954: 40. Type species: Centromeromyia eremita Frey, 1954, original designation. -Zatwarnicki, 1991: 329 [synonymy].

Diagnosis. Scatophila is distinguished from other genera of the tribe Scatellini by the following combination of characters: Very small shore flies, body length $0.80-2.00 \mathrm{~mm}$. Head: Frons mostly dull without distinct ocellar triangle; generally 1 fronto-orbital seta (some Neotropical species with 2). Antenna short, dark colored; pedicel with strong seta ventrally; basal flagellomere round; arista almost bare, without long dorsal branches. Face projected, sometimes central portion membranous and distinctly incised or oral margin with medial process (sexual dimorphism is frequently evident in the conformation of the face); facial setae conspicuous, exceptionally directed upwards, inserted mostly in the middle and ventral portions of face, 4-8 setae on the oral margin. Eye nearly round. Genal seta generally present; genal height variable. Maxillary palpus elongate, mostly dark, exceptionally yellow. Thorax: Mesonotum microtomentose, appearing with a multicolorus pattern of bands and/or spots in many species; generally 2 postsutural dorsocentral setae, rarely 3 (then with 1 presutural seta); scutellum flat, disc bare, bearing 4 posterior setae laterally; pleurae generally gray, lighter than mesonotum; stem of halter short, head oval, white. Wing faintly to conspicuously infuscate with white spots distributed over most of wing, but exceptionally within cell $\mathrm{R}_{1}$; costa short, extended to vein $\mathrm{R}_{4+5}$; wings reduced in a few species. Legs typical, usually without distinct setae (ventral row of spinulae on mid tibiae of males of some species); color of tarsi variable. Abdomen: Tergites gray microtomentose, sometimes with lighter posterior margins, or entirely shining black. Male terminalia as follows: epandrium a closed plate; cerci completely round, rarely separated anteriorly; gonites elongate, sharply terminated, sometimes bearing setae on dorsal margin of anterior portion; hypandrium as a more or less sinuous band; phallapodeme broad on margin connected to dorsal aedeagal opening; aedeagus shoe-shaped in lateral 

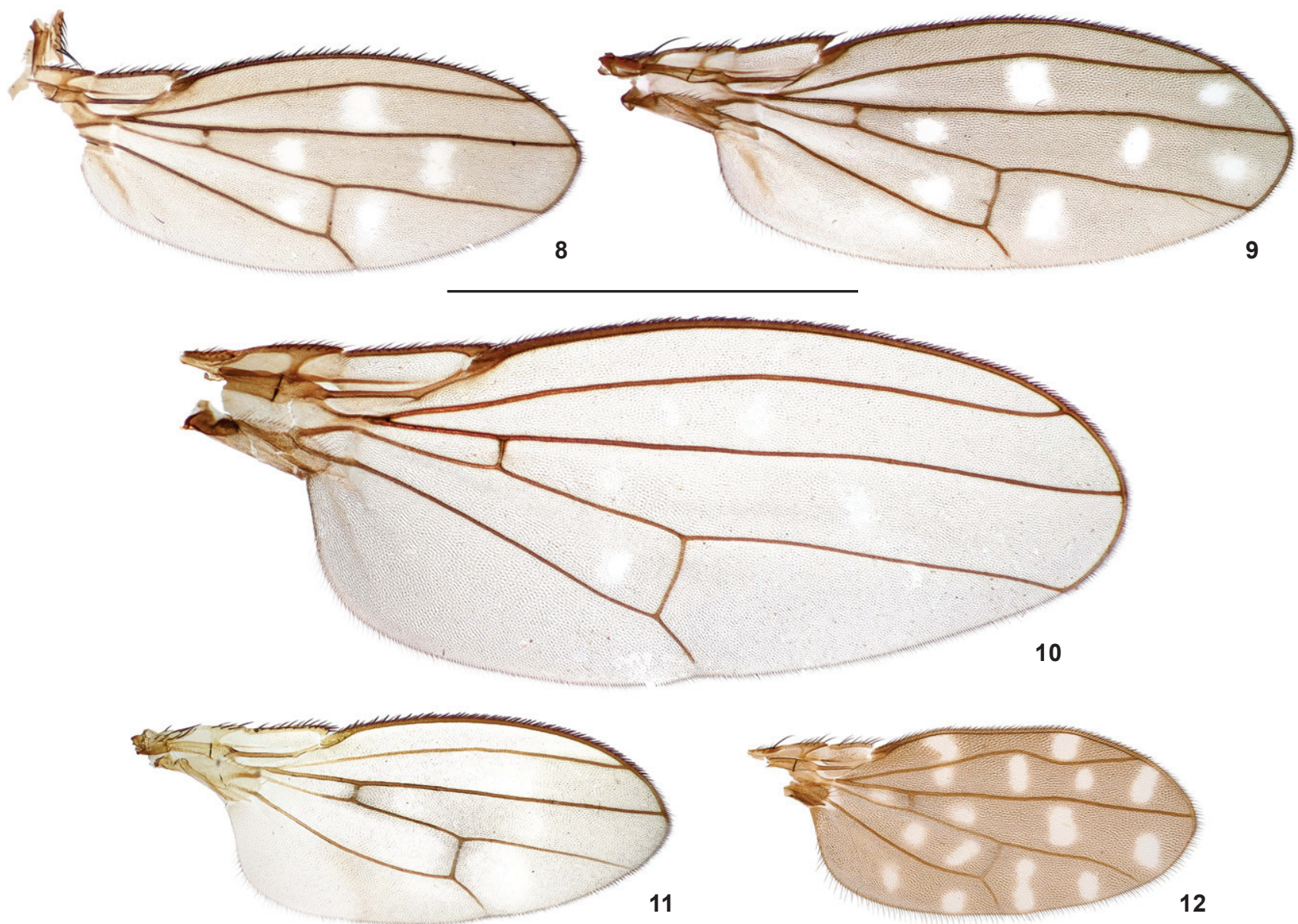

Figures 8-12. Wings, dorsal view: (8) Scatella praia sp. nov., Brazil, Paraná: Antonina: (9) Scatella rara sp. nov. Brazil, Paraná: Curitiba, Parque Iguaçu; (10) Scatella plaumanni sp. nov., Brazil, Santa Catarina: Nova Teutônia; (11) Scatophila prainha sp. nov., Brazil, Paraná: Prainha (5 km S Matinhos); (12) Scatophila dianneae sp. nov., Brazil, Paraná: Curitiba (Universidade Federal do Paraná, Reserva Biológica Mata Viva). Scale bar: $1.0 \mathrm{~mm}$.

view, in most species bearing narrow, un- or paired sinuous ventral process that originates from ventral side of distal aedeagal margin; ejaculatory apodeme lacking.

Discussion. As is the case for Scatophila in the Neotropical Region generally, there are undoubtedly additional congeners to be discovered and described from Brazil. Many undescribed species are known from Andean countries where Scatophila is especially diverse at higher elevations.

\section{Key to Species of Scatophila from Brazil}

1. Gena high, subequal to height of eye; frons silvery white to gray; 2 lateroclinate, fronto-orbital setae (Figs 11, 26-28)..... S. prainha sp. nov.

1 '. Gena low, at most $1 / 3$ height of eye; frons mostly to entirely brown; 1 lateroclinate, fronto-orbital seta (Figs 13-15, 2021). .. 2
2. Wing generally brown with numerous, conspicuous white spots; vein $\mathrm{R}_{2+3}$ conspicuously sinuous, cell $\mathrm{R}_{2+3}$ with 4 white spots, cell $\mathrm{R}_{4+5}$ with 2 spots (Fig. 12); abdomen mostly bare, shiny black $S$. dianneae sp. nov.

2 '. Wing generally lightly infuscate with $4-5$ faint, white spots; vein $R_{2+3}$ shallowly arched, not sinuous; cell $R_{2+3}$ with a single white spot; abdomen mostly densely microtomentose, gray to grayish brown S. darrowae sp. nov.

\section{Scatophila darrowae sp. nov. \\ Figs 13-19}

Diagnosis. This species is distinguished from related congeners by the following combination of characters: Small shore flies, body length $1.35-1.90 \mathrm{~mm}$; generally gray to grayish brown. Head (Figs 13-15): Gena-to-eye ratio 0.32-0.36. Thorax: Wing generally lightly infuscate with 4-5 faint, white spots; 

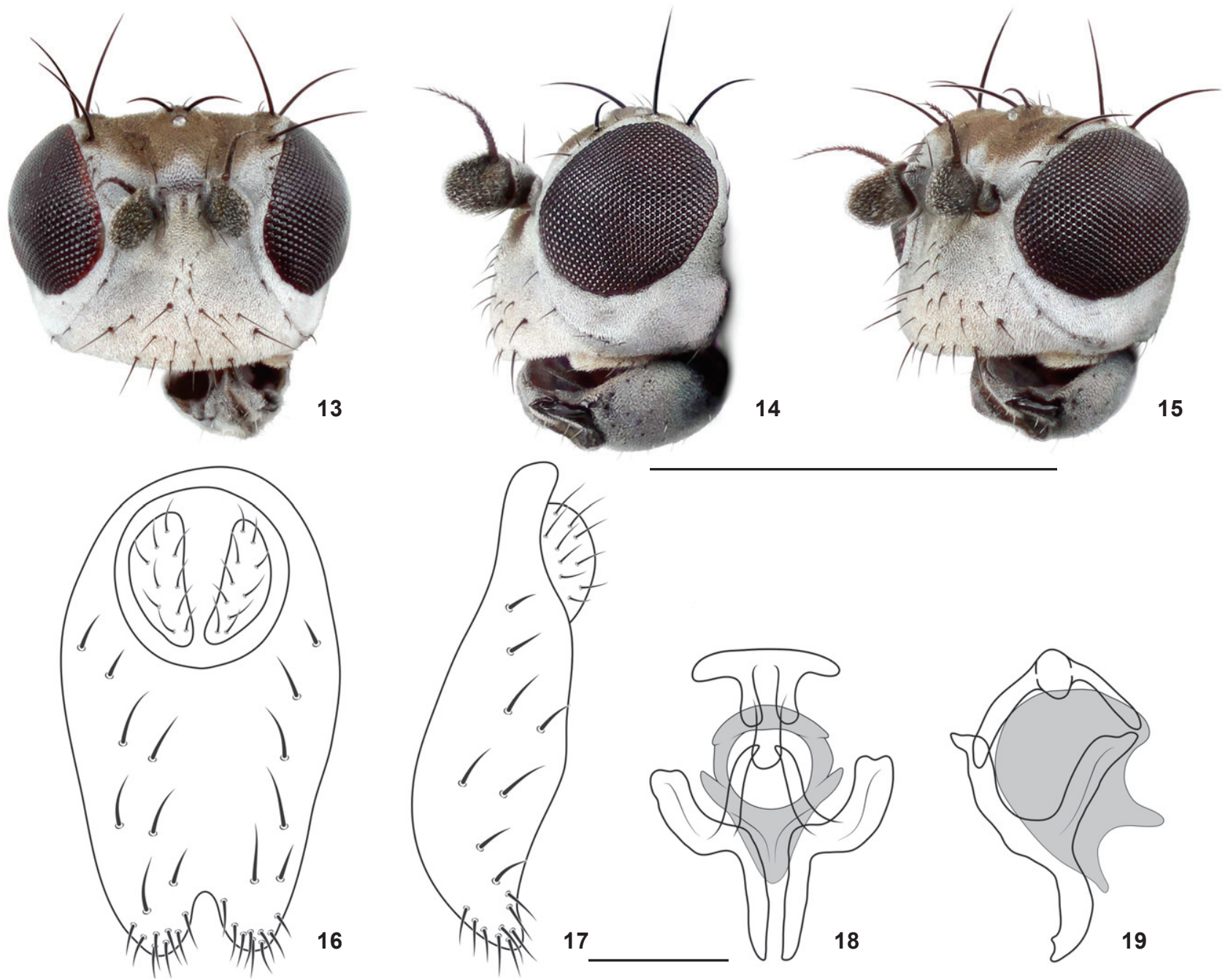

Figures 13-19. Scatophila darrowae sp. nov., Brazil, Paraná: Bocaiúva do Sul: (13) head, anterior view; (14) same, lateral view; (15) same, oblique view; (16) epandrium and cercus, posterior view; (17) same, lateral view; (18) aedeagus, gonite, neohypandrium, phallapodeme, ventral view; (19) same, lateral view. Scale bars: 13-15=0.5 mm, 16-19=0.1 mm.

vein $\mathrm{R}_{2+3}$ shallowly arched, not sinuous; cell $\mathrm{R}_{2+3}$ with a single white spot; costal vein ratio 0.18-0.25; $\mathrm{M}$ vein ratio 0.54-0.64. Abdomen: Tergites mostly densely microtomentose, gray to grayish brown, anterior margins brown, posterior portions grayer. Male terminalia (Figs 16-19): Distal margin of epandrium in posterior view (Fig. 16) medially incised, incision moderately narrow and deep, width of lobe on either side twice width of incision; epandrium in lateral view (Fig. 17) shoe-like with apex slightly curved posteriorly and pointed; cercal cavity round with semi-hemispherical cerci; aedeagus in lateral view (Fig. 19) generally compact, anterior margin rounded, posterior margin with 1 short, narrow, subapical prong, apex pointed, in ventral view (Fig. 18) generally round except for pointed ventral apex; phallapodeme in lateral view (Fig. 19) L-shaped with arms subequal, inner margin of $\mathrm{L}$ with bump at vertex and with a short extension on arm extended to base of aedeagus, in ventral view (Fig. 18) compactly T-shaped, crossbar twice length of stem; gonite in lateral view (Fig. 19) irregularly Y-shaped, ventral extension, the stem of the Y, slightly swollen, pointed apically, arms subequal in width and length, in ventral view (Fig. 18) with 2 right angle bends, wider basally, thereafter toward apex tapered, apex narrowly rounded; neohypandrium reduced.

Type material. The holotype male is labeled "BRAZIL. Paraná: Bocaiúva do Sul ( $25^{\circ} 14.9^{\prime} \mathrm{S}, 49^{\circ} 08.9^{\prime} \mathrm{W}, 890$ m), 2-4Nov 2010[,] D. and W. N. Mathis/HOLOTYPE ơ Scatophila darrowae Mathis, Marinoni \& Costa DZUP [red]." Nineteen paratypes (120', 7\%; DZUP, USNM) bear the same label data as the holo- 
type. Other paratypes are as follows: BraziL, Paraná: Curitiba (Universidade Federal do Paraná, Reserva Biológica, 2526.9'S, $\left.49^{\circ} 14^{\prime} \mathrm{W} ; 915 \mathrm{~m}\right), 9-22$ Dec 2009, D. and W.N. Mathis leg. (10', 1\%; DZUP, USNM); Prainha (5 km S Matinhos; $25^{\circ} 51.2^{\prime} \mathrm{S}$, $48^{\circ} 33.6^{\prime} \mathrm{W}$; beach), 15 Nov 2010, D. and W.N. Mathis leg. (50', 4\%; DZUP, USNM).

Type locality. Brazil, Paraná: Bocaiúva do Sul (ca. 10 km

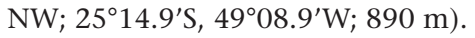

Distribution. Neotropical: Argentina, Brazil (Paraná), Ecuador, Peru, Uruguay.

Etymology. The species epithet, darrowae, is a Latin genitive patronym to honor Karolyn Darrow, who expertly took the photographs of heads and wings that are published in this paper and that greatly enhance recognition of those species.

Remarks. This species is similar and apparently closely related to $S$. avida Cresson, especially externally. Structures of the male terminalia, especially the shape of the ventral epandrial margin, distinguish this species from congeners, including $S$. avida.

\section{Scatophila dianneae sp. nov. Figs $12,20-25$}

Diagnosis. This species is distinguished from related congeners by the following combination of characters: Small shore flies, body length 1.10-1.30 mm; generally dark brown to black. Head (Figs 20-21): Mesofrons dark brown with a faint gray, lateral stripe. Face with dorsal hump brown and with moderately wide brown stripe on each side of face just dorsad of epistomal margin, otherwise face gray to tan. Gena very low with gena-toeye ratio 0.06-0.08. Thorax: Mesonotum mostly dark brown with medial stripe gray anteriorly and posteriorly and with spots laterally at posterior $1 / 3$ and with 2 wider stripes anteriorly on either side of acrostichal track; with a presutural spot laterad of dorsocentral track and a long, postsutural gray stripe; postpronotum gray and with gray area anterodorsad of notopleuron; apex of scutellum gray; notopleuron and rest of pleural area mostly dark brown but with gray horizontal stripe just ventrad of notopleuron. Wing (Fig. 12) generally brown with numerous, conspicuous white spots; vein $\mathrm{R}_{2+3}$ conspicuously sinuous, cell $\mathrm{R}_{2+3}$ with 4 white spots, cell $\mathrm{R}_{4+5}$ with 2 spots; costal vein ratio 0.59-0.61; $\mathrm{M}$ vein ratio 0.54-0.64. Coxae and femora black to blackish brown; tibiae brown; tarsi brown, becoming darker brown apically. Abdomen: Tergites moderately bare, subshiny to shiny, with some gray areas laterally on tergites 3-4. Male terminalia (Figs 22-25): Ventral epandrial margin in posterior view (Fig. 22) broadly bilobed with wide, rounded V-shaped gap between lobes, apex of each lobe rounded, in lateral view (Fig. 23) with apical $3 / 4$ more or less rectangular, dorsal $1 / 4$ strap-like; aedeagus in lateral view (Fig. 25) deeply incised basally and with a secondary, shallow, wide gap posteriorly toward base, remainder of aedeagus broadly sack-like, with a long, slender, curved ventral aedeagal process, in ventral view (Fig. 24) broadly ovate; phallapodeme in lateral view (Fig. 25) L- shaped with short, knob-like keel; in ventral view (Fig. 24) as a spool; gonite in lateral view (Fig. 25) more or less Y-shaped with arms projected anteriorly, apex of gonite truncate, setulose, in ventral view (Fig. 24) with lateral projection thin, elongate, curved, thickened basally, acutely pointed apically, anterior arm band-like, extended to base of phallapodeme; neohypandrium in lateral view (Fig. 25) elongate, slender, nearly straight.

Type material. The holotype male of Scatophila dianneae is labeled "BRAZIL. Paraná: Curitiba, UFPR [Universidade Federal do Paraná, Reserva Biológica Mata Viva] $\left(25^{\circ} 26.9^{\prime} \mathrm{S}\right.$, $49^{\circ} 14^{\prime}$ W; 915 m), 28-31Dec 2009[,] D. \& W. N. Mathis/HOLOTYPE ơ Scatophila dianneae Mathis, Marinoni \& Costa DZUP [red]." The holotype is double mounted (minuten in a block of plastic), is in excellent condition (right wing removed and slide mounted, some setae missing), and is deposited in DZUP. Paratypes are as follows: BraziL, Santa Catarina: Nova Teutônia

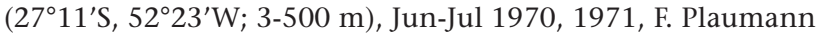
leg. (20'; MZUSP, USNM); São Bento do Sul (26¹5.2'S, 49 22.8’ W), 16-19 Oct 2001 (10'; MZUSP).

Type locality. BraziL, Paraná: Curitiba, Universidade Federal do Paraná, Reserva Biológica Mata Viva (2526.9'S, 49¹4’W; $915 \mathrm{~m})$.

Distribution. Neotropical: Brazil (Paraná, Santa Catarina). Etymology. The species epithet, dianneae, is a Latin genitive patronym to honor N. Dianne Mathis, who collected the holotype of this species. Dianne is also a unique and colorful friend and companion and the wife of the first author.

Remarks. This species is readily distinguished from congeners by the wing pattern of markings and venation. The shapes of the head and of structures of the male terminalia also distinguish this species.

\section{Scatophila prainha sp. nov.}

Figs 11, 26-32

Diagnosis. This species is distinguished from related congeners by the following combination of characters: Moderately small shore flies, body length $2.00-2.65 \mathrm{~mm}$; generally whitish gray to gray. Head (Figs 26-28): Frons as long as wide, mostly silvery white, mesofrons gray and bordered anteriorly by small setulae; 2 lateroclinate, fronto-orbital setae; ocellar setae well developed, equal to medial vertical seta; pseudopostocellar setulae minute, partially divergent. Antenna gray, pedicel faintly orange; arista short, length subequal to length of basal flagellomere, micropubescent. Face projected, faintly yellowish silver to silvery gray; with slight, medial swelling anterior of antennal bases, antennal grooves barely evident; with prominent lateroclinate facial seta and longer setae along epistomal margin, a few setulae medioventrally arranged in circle; $2-3$ setulae at frontal suture; parafacial becoming wider ventrolaterally. Gena very high, gena-to-eye ratio $0.60-0.69$, generally lacking setae or setulae except for 1 seta toward posteroventral corner. Maxillary palpus yellow; otherwise mouthparts mostly gray. Thorax: Acrostichal setulae in 2 rows, well developed al- 

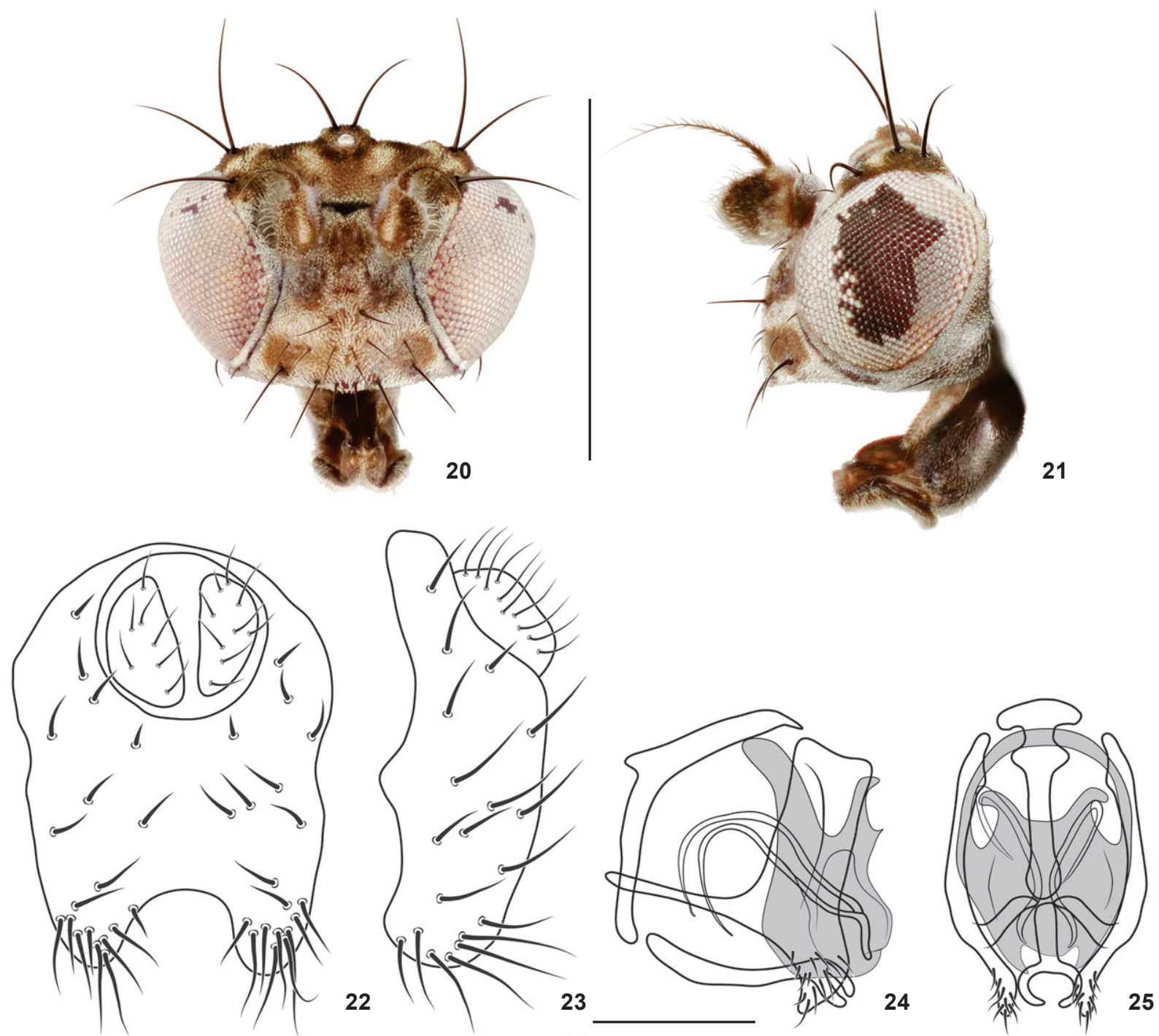

Figures 20-25. Scatophila dianneae sp. nov., Brazil, Paraná: Curitiba (Universidade Federal do Paraná, Reserva Biológica Mata Viva): (20) head, anterior view; (21) same, lateral view; (22) epandrium and cercus, posterior view; (23) same, lateral view; (24) aedeagus, gonite, neohypandrium, phallapodeme, ventral view; (25) same, lateral view. Scale bars: $20-21=0.5 \mathrm{~mm}, 22-25=0.1 \mathrm{~mm}$.

though size irregular, posterior pair larger and more widely separated; $3(1+2)$ dorsocentral setae; presutural and postsutural supra-alar setae well developed; 2 scutellar setae, 1 lateral, other apical; 2 notopleural setae, posterior seta about half length of anterior seta, inserted at level of anterior seta; 1 anepisternal seta at posterior margin near midheight; 1 katepisternal seta; pleural area generally silvery gray. Wing (Fig. 11) generally faintly infuscate with faint white areas, these not well defined, base of wing yellowish, becoming slightly darker anteriorly and apically; vein $\mathrm{R}_{2+3}$ elongate, costal vein ratio 0.15-0.17; $\mathrm{M}$ vein ratio 0.67-0.69. Coxae and femora gray to whitish gray, apices of femora yellow; tibiae yellow with whitish microtomentum; tarsi yellow. Abdomen: Tergites mostly bare, whitish gray to gray similar to mesonotum. Male terminalia (Figs 29-32): Distal margin of epandrium in posterior view (Fig. 29) widely incised, incision U-shaped, width of each ventrolateral arm about equal to width of incision, in lateral view as in Fig. 30; aedeagus in ventral view (Fig. 31) irregularly rectangular with shallow but long lateral flanges, in lateral view (Fig. 32) robustly slipperlike, deeply incised basally, apex pointed and curved; phallapodeme in lateral view (Fig. 32) boomerang-like, in ventral view (Fig. 31) spool-like, narrower toward base; gonite in lateral view (Fig. 32) irregularly Y-shaped, robustly developed, base or stem short, pointed apically, bearing 2 longer setulae 

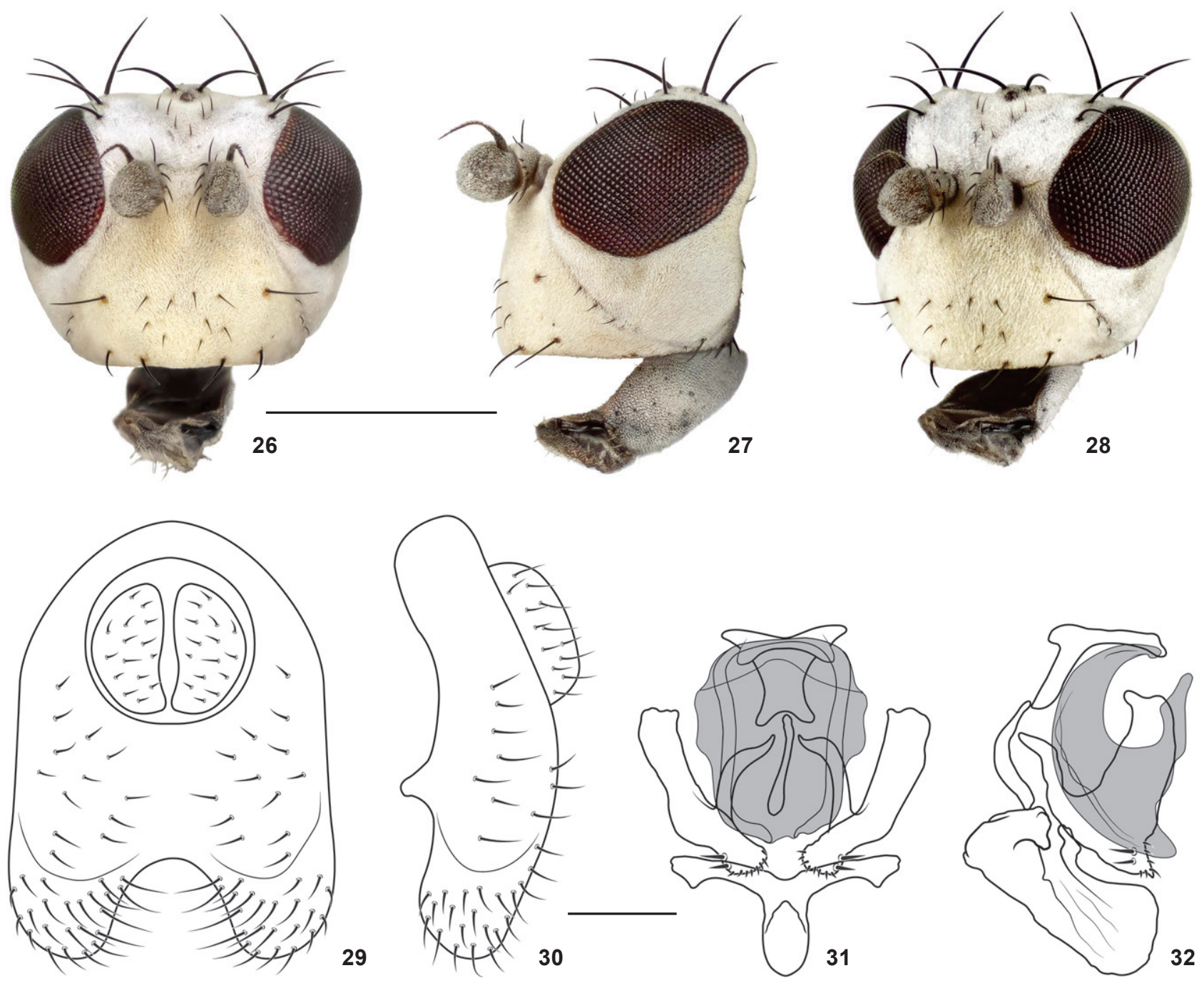

Figures 26-32. Scatophila prainha sp. nov., Brazil, Paraná: Prainha (5 km S Matinhos): (26) head, anterior view; (27) same, lateral view; (28) same, oblique view; (29) epandrium and cercus, posterior view; (30) same, lateral view; (31) aedeagus, gonite, neohypandrium, phallapodeme, ventral view; (32) same, lateral view. Scale bars: $26-28=0.5 \mathrm{~mm}, 29-32=0.1 \mathrm{~mm}$.

subapically, posterior arm robust, $4 \mathrm{X}$ width of anterior arm, anterior arm elongate, narrow, slender; neohypandrium in lateral view (Fig. 32) slender, curved, elongate; sternite 5 in ventral view (Fig. 31) T-shaped, crossbar at posterior end, in lateral view (Fig. 32) more or less rectangular.

Type material. The holotype male of Scatophila prainha is labeled "BRAZIL. Paraná: Prainha ([5 km] S Matinhos; $25^{\circ} 51.2^{\prime} \mathrm{S}, 48^{\circ} 33.6^{\prime} \mathrm{W}$; beach), 15Nov2010, D. \& W. N. Mathis/ HOLOTYPE ơ Scatophila prainha Mathis, Marinoni \& Costa DZUP [red]." The holotype is double mounted (minuten in a block of plastic), is in excellent condition, and is deposited in DZUP. Two paratypes (10", 1\%; DZUP, USNM) bear the same locality label as the holotype.
Other specimens examined. BrazIL, Rio Grande do Sul: Torres $\left(29^{\circ} 21^{\prime} \mathrm{S}, 49^{\circ} 44^{\prime} \mathrm{W}\right)$, Jun 1965, N. Papavero leg. (10'; MZUSP); Tramandaí (Praia do Tramandaí; $\left.29^{\circ} 56.5^{\prime} \mathrm{S}, 50^{\circ} 07.8^{\prime} \mathrm{W}\right), 20$ May1 Jul 2013, R.M. Carvalho, C. Ozorio leg. (10", 6o; DZUP).

Type locality. Brazil, Paraná: Prainha (5 km S Matinhos; $25^{\circ} 51.2^{\prime} \mathrm{S}, 48^{\circ} 33.6^{\prime} \mathrm{W}$; beach).

Distribution. Neotropical: Brazil (Paraná, Rio Grande do Sul).

Etymology. The species epithet, prainha, is the name of the beach in southern Brazil (Paraná) where this species was first collected and is a noun in apposition.

Remarks. This is the first species of the so-called "primitive group" (ZATWARNICKI \& Mathis 1994) to be found in Brazil. 
The "primitive group" is characterized by having two lateroclinate, fronto-orbital setae (all other congeners have a single seta). In Chile and Peru there are additional species of this group, all undescribed.

\section{ACKNOWLEDGMENTS}

We gratefully acknowledge the assistance and cooperation of many organizations and individuals who contributed to the field work and production of this paper. Karolyn Darrow expertly produced the photographs of heads, especially the faces and wings, and she also assembled the plates. For reviewing a draft of this paper we thank Tadeusz Zatwarnicki.

Field work in Brazil (December 2009-June 2010) that resulted in the vast majority of specimens studied in this paper was supported by a grant from CNPq (Visiting Researcher/Process number 401609/2009-0), which we gratefully acknowledge and thank. We thank Dianne Mathis for helping with all aspects of the production of this paper, especially the field work in Brazil. We also thank A. Bernardo Carvalho and his lab (Elisa, Monica, Susana) for hosting us while conducting field work along the coast of São Paulo.

\section{LITERATURE CITED}

BeCKer, Th. 1896. Dipterologische Studien IV. Ephydridae. Berliner Entomologische Zeitschrift 41 (2): 91-276.

BECKer, Th. 1905. Ephydridae, p. 185-215. In: T. BECKer; M. Bezzl; K. Kertész \& P. Stein (Eds). Katalog der paläarktischen Dipteren. Budapest, G. Wesselényi in Hódmezövásárhely, vol. 4, 328p.

Blair, J.M. \& B.A. Foote. 1984. Resource partitioning in five sympatric species of Scatella (Diptera: Ephydridae). Environmental Entomology 13 (5): 1336-1339.

Clausen, P.J. \& E.F. Cook. 1971. A revision of the Nearctic species of the tribe Parydrini (Diptera: Ephydridae). Memoirs of the American Entomological Society 27: 1-150.

Cogan, B.H. 1980. 71. Family Ephydridae, p. 655-669. In: R.W. Crosskey (Ed.). Catalogue of the Diptera of the Afrotropical Region. London, British Museum (Natural History), 1437p.

Cogan, B.H. 1984. Family Ephydridae, p. 126-176. In: Á. Soós \& L. PAPP (Eds). Catalogue of Palaearctic Diptera 10. Amsterdam, Elsevier Science Publishers and Akadémiai Kiadó, 402p.

Cogan, B.H. \& W.W. WirTh. 1977. Family Ephydridae, p. 321339. In: M.D. Delfinado \& D.E. Hardy (Eds). A catalogue of the Diptera of the Oriental Region. Volume III. Suborder Cyclorrhapha (excluding Division Aschiza). Honolulu, University Press of Hawaii, 451+VIIp.

Colun, J.E. 1930. Some new species of the dipterous genus Scatella Dsv. and the differentiation of Stictoscatella gen. nov. (Ephydridae). The Entomologist's Monthly Magazine 66: 133-39.
Coquillett, D.W. 1910. The type-species of the North American genera of Diptera. Proceedings of the United States National Museum 37: 499-647.

Cresson JR, E.T. 1930. Studies in the dipterous family Ephydridae. Paper III. Transactions of the American Entomological Society 56: 93-131.

Cresson JR, E.T. 1934. Descriptions of new genera and species of the dipterous family Ephydridae.ÄXI. Transactions of the American Entomological Society 60: 199-222.

CRESSON JR, E.T. 1935. Descriptions of new genera and species of the dipterous family Ephydridae. Transactions of the American Entomological Society 61: 345-372.

DAHL, R.G. 1959. Studies on Scandinavian Ephydridae (Diptera Brachycera). Opuscula Entomologica Supplementum 15: $1-224$.

DudA, O. 1942. Neue oder ungenügend bekannte Zweiflügler der paläarktischen Region aus meiner Sammlung. 2. Fortsetzung. Deutsche Entomologische Zeitschrift 1942 (1-4): 1-39.

FreY, R. 1954. Diptera Brachycera und Sciaridae von Tristan da Cunha (with a Contribution by J. Becquaert, Cambridge, USA). Results of the Norwegian Scientific Expedition to Tristan da Cunha 4 (26): 1-55.

Grimaldi, D.A. 1987. Phylogenetics and taxonomy of Zygothrica (Diptera, Drosophilidae). Bulletin of the American Museum of Natural History 186: 103-268.

Lizarralde de Grosso, M.S. 1989. Ephydridae de la República Argentina (Insecta - Diptera). Tucumán, Facultad de Ciencias Naturales y Instituto Miguel Lillo Universidad Nacional de Tucumán, Serie Monográfica y Didáctica 3, 93p.

Malloch, J.R. 1925. Notes on Australian Diptera. No. VII. Proceedings of the Linnean Society of New South Wales 50 (4): 311-340.

Malloch, J.R. 1933. Some Acalyptrate Diptera from the Marquesas Islands. Bulletin of the Bernice P. Bishop Museum 114: 3-31.

Mathis, W.N. 1978. A revision of the Nearctic species of Limnellia Malloch (Diptera: Ephydridae). Proceedings of the Biological Society of Washington 91 (1): 250-293.

MathIs, W.N. 1980. Studies of Ephydrinae (Diptera: Ephydridae), III: Revision of some Neotropical genera and species. Smithsonian Contributions to Zoology 303: 50+IVp.

Mathis, W.N. 1986. Studies of Psilopinae (Diptera: Ephydridae), I: A revision of the shore fly genus Placopsidella Kertész. Smithsonian Contributions to Zoology 430: 30+IVp.

Mathis, W.N. 1997. The shore flies of the Belizean Cays (Diptera: Ephydridae). Smithsonian Contributions to Zoology 592: 77+VIp.

Mathis, W.N. \& J.F. EDmiston. 1991. S. W. Williston's species of Ephydridae (Diptera) from St. Vincent (West Indies). Proceedings of the Biological Society of Washington 104 (4): 816-839.

Mathis, W.N. \& G.E. Shewell. 1978. Studies of Ephydrinae (Diptera: Ephydridae), I: Revisions of Parascatella Cresson 
and the triseta Group of Scatella Robineau-Desvoidy. Smithsonian Contributions to Zoology 285: 44+IVp.

Mathis, W.N. \& W.W. WIRTH. 1981. Studies of Ephydrinae (Diptera: Ephydridae), IV: Revision of the Australian species of subgenus Neoscatella Malloch. Smithsonian Contributions to Zoology 325: 27+IVp.

Mathis, W. N. \& T. Zatwarnicki. 1990a. A revision of the Western Palearctic species of Athyroglossa (Diptera: Ephydridae). Transactions of the American Entomological Society 116 (1): 103-133.

Mathis, W.N. \& T. Zatwarnicki. 1990b. Taxonomic notes on Ephydridae (Diptera). Proceedings of the Biological Society of Washington 103 (4): 891-906.

Mathis, W.N. \& T. Zatwarnicki. 1995. A world catalog of the shore flies (Diptera: Ephydridae). Memoirs on Entomology, International 4: $\mathrm{VI}+423 \mathrm{p}$.

Mathis, W.N. \& M.A. Zumbado. 2005. Description of Scatella savegre, a new species from Costa Rica in the triseta group (Diptera: Ephydridae). Proceedings of the Entomological Society of Washington 107 (2): 386-391.

McAlpine, J.F. 1981. Morphology and Terminology-Adults, pp. 9-63. In: J.F. McAlpine; B.V. Peterson; G.E. Shewell; H.J. TesKey; J.R. Vockeroth \& D.M. Wood (Eds). Manual of Nearctic Diptera. Ottawa, vol. 1, 674p.

OlafsSon, E. 1991. Taxonomic revision of western Palaearctic species of the genera Scatella R.-D. and Lamproscatella Hendel, and studies on their phylogenetic positions within the subfamily Ephydrinae (Diptera, Ephydridae). Entomologica Scandinavica Supplement 37: 1-100.

Robineau-Desvoidy, J.B. 1830. Essai sur les Myodaires. Mémoires Préséntes par divers Savans a l'Académie Royale des Sciences de l'Institut de France et Imprimés par son Ordre, Sciences Mathématiques et Physiques 2 (2): 1-813.

RoNDANI, C. 1856. Dipterologiae italicae prodromus. genera Italica ordinis dipterorum ordinatim disposita et distincta et in familias et stirpes aggregata. Parma, A.
Stoschi, vol. 1, 228p.

Stuckenberg, B.R. 1999. Antennal evolution in the Brachycera (Diptera), with a reassessment of terminology relating to the flagellum. Studia Dipterologica 6: 33-48.

Sturtevant, A.H. \& M.R. Wheeler. 1954. Synopses of Nearctic Ephydridae (Diptera). Transactions of the American Entomological Society 79: 151-257.

WiLliston, S.W. 1896. On the Diptera of St. Vincent (West Indies). Transactions of the Entomological Society of London 1896: 253-446.

WirTh, W.W. 1965. Ephydridae, p. 734-759. In: A. STONE; C.W. Sabrosky; W.W. Wirth; R.H. Foote \& J.R. Coulson (Eds). A Catalog of the Diptera of America North of Mexico. Washington, D.C., U.S. Department of Agriculture, Handbook 276, 1696p.

WIRTh, W.W. 1968. 77. Family Ephydridae, p. 1-43. In: N. PAPAVERO (Ed.). A Catalogue of the Diptera of the Americas South of the United States. São Paulo, Departamento de Zoologia, Secretaria da Agricultura.

Wirth, W.W. \& A. Stone. 1956. Aquatic Diptera, p. 372-482. In: R.L. Usinger. (Ed.). Aquatic Insects of California. Berkeley, University of California Press, 508+Xp.

ZatWARNicki, T. 1987. New synonyms and records of Palearctic Scatophila (Diptera, Ephydridae). Polskie Pismo Entomologiczne 57 (2): 277-298.

ZATWARNICKI, T. 1991. Changes in nomenclature and synonymies of some genera and species of Ephydridae (Diptera). Deutsche Entomologische Zeitschrift 38 (4-5): 295-333.

ZatWARNICKI, T. 1996. A new reconstruction of the origin of eremoneuran hypopygium and its classification implications (Insecta: Diptera). Genus 7 (1): 103-175.

Zatwarnicki, T. \& W.N. Mathis. 1994 [1993]. Phylogeny and classification of the genus Scatophila Becker (Diptera: Ephydridae). Annales de la Société Entomologique de France 29 (4): 351-370.

Submitted: 10.IX.2014; Accepted: 05.XI.2014.

Editorial responsibility: Gabriel L.F. Mejdalani 